\title{
Modelling the Current and Future Spatial Distribution Area of Shea Tree (Vittelaria paradoxa C. F. Gaertn) in the Context of Climate Change in Benin
}

\author{
Yasminath Judith Follone Avaligbé $1^{*}$, Faki Oyédékpo Chabi ${ }^{1}$, Césaire Paul Gnanglè², \\ Orou Daouda Bello1, Ibouraïma Yabi ${ }^{3}$, Léonard Ahoton'1, Aliou Saïdou' \\ ${ }^{1}$ Integrated Soil and Crop Management Research Unit, Laboratory of Soil Sciences, Crop Sciences School, Faculty of Agronomic \\ Sciences, University of Abomey-Calavi, Abomey-Calavi, Benin \\ ${ }^{2}$ Agricultural Research Centre (CRA) of Agonkanmey, National Agricultural Research Institute of Benin (INRAB), Cotonou, \\ Benin \\ ${ }^{3}$ Laboratory Pierre PAGNEY “Climate, Water, Ecosystem and Development (LACEEDE)”, Department of Geography and Land \\ Management (DAGT), Faculty of Human and Social Sciences (FASHS), University of Abomey-Calavi, Abomey-Calavi, Benin \\ Email: *yasminathavaligbe@gmail.com
}

How to cite this paper: Avaligbé, Y. J. F., Chabi, F. O., Gnanglè, C. P., Bello, O. D., Yabi, I., Ahoton, L., \& Saïdou, A. (2021). Modelling the Current and Future Spatial Distribution Area of Shea Tree (Vittelaria paradoxa C. F. Gaertn) in the Context of Climate Change in Benin. American Journal of Climate Change, 10, 263-281. https://doi.org/10.4236/ajcc.2021.103012

Received: April 26, 2021

Accepted: August 30, 2021

Published: September 2, 2021

Copyright $\odot 2021$ by author(s) and Scientific Research Publishing Inc. This work is licensed under the Creative Commons Attribution International License (CC BY 4.0).

http://creativecommons.org/licenses/by/4.0/ (c) (i) Open Access

\begin{abstract}
In Benin, Shea tree (Vitellaria paradoxa) is one of the agroforestry species of great socio-economic importance for local populations. Given the actual variation in the climate parameters, it is necessary to anticipate the future spatial distribution of Shea trees as an adaptation strategy and for designing relevant conservation strategies. The aim of the present research was to evaluate the influence of climate change on the distribution areas of Shea trees in Benin. Occurrence data consisting of geographic coordinates of Shea trees in Benin as well as bioclimatic variables were recorded. Furthemore, additional presence points were collected from the Global Biodiversity Information Facility database website. Current and future environmental data for the study area were obtained from the Africlim website. Bioclimatic variables (moisture and temperature), monthly maximum and minimum temperatures and annual rainfall were collected from Worldclim synoptic stations website for the period 1970-2000. The aridity index was created from the potential evapotranspiration (PET) and annual rainfall, using spatial analysis tools of ArcGIS. The impact of current and future environmental conditions on favourable Shea trees' growing area was assessed following the maximum entropy (MaxEnt) approach under two climate scenarios (RCP 4.5 and RCP 8.5). Under the current climate conditions, $80 \%$ of Benin territory and $79 \%$ of the protected areas were highly favourable for Shea trees growing and conservation. How-
\end{abstract}


ever, all climate scenarios projected the significant decrease of $14 \%$ to $19 \%$ of the distribution of favourable for Shea tree growing area and $26 \%$ to $30 \%$ of the protected areas by 2055 in favour of non-favourable for the trees' distribution. The protection of habitats favourable for the species development, coupled with a quick restoration of the species through the use of appropriate vegetative propagation techniques are required to sustain the species' conservation in Benin and maintain farmers' livelihood.

\section{Keywords}

Bioclimatic Variables, Agroforestry, Scenario Analysis, Adaptation Strategy, Conservation

\section{Introduction}

Plant genetic resources are an important component of biodiversity that contribute to food security and improved livelihoods (World Agroforestry Centre, 2008). In Africa, non-timber forest products (NTFPs) are used by people to meet their daily needs for food, nutrition, health products and household energy. Integrating NTFPs into productive agricultural areas has been recommended to sustain African livelihoods and protect the environment (Leakey, 2010). Shea tree (Vitellaria paradoxa C. F. Gaertn) is one of the species relevant to these objectives mentioned above (Avaligbé et al., 2021).

The shea tree is a multipurpose species with great uses and socio-economic importance. It provides the inhabitants of tropical Africa with food, medicinal, handicrafts (Diarrassouba et al., 2008; Gnanglè, 2017). The socio-economic and ecosystem services provided by shea tree have made it a first order species on the priority list of African genetic resources (FAO, 1989). In addition to covering food needs during the lean season and providing income to households through the marketing of the nuts, shea trees conserve soil moisture, protect the soil from rain erosion through its roots (Jonsson et al., 1999; Traoré, 2003, Diarrassouba et al., 2008). In Benin, shea trees are present in various habitats (fields, fallows, parks, etc.) where they are intensively exploited to improve livelihood of the populations. This increasing pressure on the shea tree resulted in the species decline with a serious threat of extinction in the species populations (Adjahossou et al., 2016; Agbo et al., 2017).

In addition, climate change poses nowadays a significant threat to shea trees (Aleza et al., 2018). Increasing temperature and/or decreasing rainfall may alter the extent and suitable habitats for the species (Padonou et al., 2015). Projections indicate that $20 \%$ - $30 \%$ of plant and animal species will face extinction risks if global warming exceeds $1.5^{\circ} \mathrm{C}-2.5^{\circ} \mathrm{C}$ in Africa (Busby et al., 2012). As a result, global diversity, and production of NTFPs will also decline due to climate change events (Idohou et al., 2017). Benin is not on the side-lines of climate change and its consequences (Yabi \& Afouda, 2012). It would therefore be im- 
portant to anticipate the future impact of climatic factors on the habitats of important agroforestry species such as shea tree to provide policy makers with decision tools to set sound conservation strategies.

Modelling based on the relationship between species occurrence points and environmental variables is an effective tool used to describe climate preferences and spatial distribution potential of species (Peterson et al., 2011). This approach is widely used in conservation and species ecology (Pearson et al., 2007; Elith et al., 2011). For instance, (Salako et al., 2018) combined geostatistical techniques and species distribution modelling to predict the potential impact of climate change on the decline of the agroforestry species Borassus aethiopum. Likewise, (Gbètoho et al., 2017) used this approach to predict the suitability and capacity of some pioneer forest species to restore secondary forests in the Lama Forest Reserve in Benin. Similarly, (Idohou et al., 2017) used niche models to identify potential spatial priorities for the conservation of wild palm species across West Africa. (Adjahossou et al., 2016) assessed the effectiveness of protected areas by projecting the potential areas suitable for cultivation and conservation of selected tree species of socioeconomic importance in Benin. All these studies revealed the usefulness of ecological niche modelling to provide information that can be derived into adequate strategies for species conservation.

Furthermore, protected areas were recently recognized as one of the appropriate systems for sustainable conservation of plant biological diversity (Marshall et al., 2012). However, the demographic explosion is leading to increased needs: leading to overexploitation of plant and animal resources. Within protected areas, NTFPs are becoming vulnerable and their protection is increasingly questionable (Castro et al., 2015). The objective of the present study was to assess the impact of current and future (horizon 2055) variation of the climatic factors on the shea tree distribution area in Benin under the Representative Concentration Pathways (RCP) 4.5 and 8.5 scenarios.

\section{Material and Methods}

\subsection{Study Area}

The study was carried out in five shea tree parks in Benin as defined by (Gnanglè, 2005) (Figure 1). The choice of these shea tree parks was based on the distribution area of shea trees in Benin. According to (Gnanglè, 2005), shea tree parks are distributed across all the three phytogeographical zones of Benin: 1) The Sudanian zone $\left(9^{\circ} 45^{\prime}-12^{\circ} 25^{\prime} \mathrm{N}\right)$, which includes the shea tree parks of Kandi and Bembereke; 2) The Sudano-Guinean zone $\left(7^{\circ} 30^{\prime}-9^{\circ} 45^{\prime} \mathrm{N}\right)$, which includes the shea tree parks of Savè and Parakou; 3$)$ The Guinean zone $\left(6^{\circ} 25^{\prime}-7^{\circ} 30^{\prime} \mathrm{N}\right)$, which includes the shea tree park of Bohicon. The Sudanian zone is characterized by a unimodal rainfall of less than $1000 \mathrm{~mm}$ with an average relative humidity of $54.9 \%$ and an average temperature of $27.5^{\circ} \mathrm{C}$. Ferric and Plintic Luvisol soils are dominant in the area. The vegetation is mainly composed of wooded savannahs. The Sudano-Guinean zone, known as the transition zone, also has a 


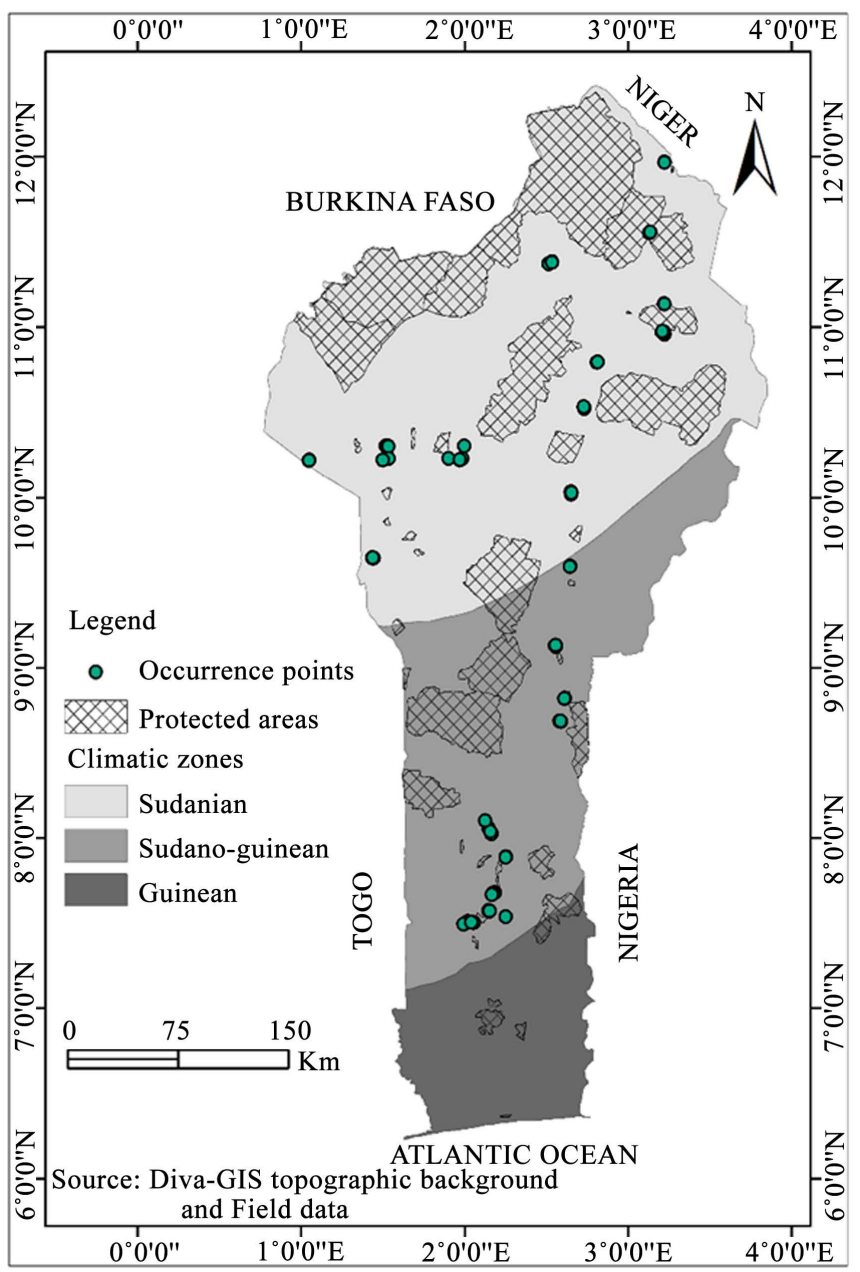

Figure 1. Study area and points of occurrence of the species.

unimodal rainfall pattern (Yabi, 2008) with an average annual rainfall of 1000 $\mathrm{mm}$. The annual temperature varies between $21.2^{\circ} \mathrm{C}$ (average of minima) and $32.5^{\circ} \mathrm{C}$ (average of maxima), while the relative air humidity ranges between $45.5 \%$ (average of minima) and $87.1 \%$ (average of maxima). This zone is dominated by ferric and plintic luvisol soils. These soils have variable fertility levels and the vegetation is characterized by mosaic of open forest and shrubby to woody savannah with forest galleries along the rivers. The Guinean zone is characterized by a bimodal rainfall pattern with an annual average of $1200 \mathrm{~mm}$. The average temperature varies between $25^{\circ} \mathrm{C}$ and $29^{\circ} \mathrm{C}$ and relative humidity between $69 \%$ and $97 \%$. Acrisols are dominant soil types in this area.

\subsection{Presentation of Shea Tree}

Shea tree (Vitellaria paradoxa) belongs to the Sapotaceae family and is mainly found in sub-Saharan Africa (SSA). It is a multipurpose species playing an important socio-economic and cultural role in Africa (Diarrassouba et al., 2008; Boffa, 2015). In Benin, this species is present in all bioclimatic zones but more represented in the Sudano-Guinean zone and the Sudanian zone (Gnanglè et al., 
2011). It is also present in the Protected Areas (PA) made up of two national parks (Pendjari Park and W Park) and 57 forest reserves, occupying 25\% of the national territory of Benin.

Shea tree grows naturally in agroforestry systems, forests, and fallows (Lamien et al., 2004; Aleza et al., 2018). The species is a tree with an average height of 7.5 $\mathrm{m}$ but can reach $12 \mathrm{~m}$ or more with an average stem diameter of $50 \mathrm{~cm}$ (Arbonnier, 2002). Shea tree is the second most important oil crop in Africa after oil palm (Nde et al., 2014). In Benin, it is the third most important cash crop after cotton and cashew. The fruit pulp is directly consumed especially during the lean season. The raw nuts are sold or processed for the shea butter used for cooking, skin care and in traditional medicine (Lovett, 2004). In addition, the latex from the bark is used in the manufacture for glue; the leaves are used as fodder for livestock (Lovett \& Haq, 2000) due to their high protein content (Sanon, 2009). The shea tree contributes to the protection of the environment through the ecosystem services it provides (Jasaw et al., 2015). Furthermore, the species had significant potential for carbon sequestration (Saïdou et al., 2012; Dimobe et al., 2019). Overexploitation of the fruits and the slaughtering of young shoots during land clearing for agriculture are the causes of the species' decline in Benin where it is red-listed by the International Union for Conservation of Nature (IUCN) according to (Neuenschwander et al., 2011) and (IUCN, 2019).

\subsection{Occurrence and Environmental Data Collection}

To model the distribution of habitats favourable for cultivation and conservation of shea trees, occurrence data and environmental data were collected. Occurrence data consisting of geographic coordinates (longitude and latitude) of shea tree occurrence sites were recorded in Benin, especially in agroforestry systems and protected areas. Additional presence points were collected from the GBIF (Global Biodiversity Information Facility; https://www.gbif.org) database. Current and future environmental data for the study region were obtained from the Africlim website (http://www.york.ac.uk/environment/research/kite/resources/) which offers the possibility to obtain climate variables with fine resolution for the entire African region (Platts et al., 2015). For future climate projections, two scenarios were considered namely the Representative Concentration Pathways (RCP) 4.5 and 8.5 which are the most appropriate for the African regions. The RCP 4.5 is the most optimistic scenario, while RCP 8.5 is the most pessimistic in terms of emission of $\mathrm{CO}_{2}$ levels and temperature increase. Future environmental data for RCP 4.5 and RCP 8.5 scenarios were obtained from Ensemble Regional climatic models. These data consisted of 21 bioclimatic variables (11 moisture variables and 10 temperature variables) and derived by interpolation of monthly maximum and minimum temperatures and annual precipitation from Worldclim weather stations (obtained from the website http://www.worldclim.org) for the period 1970-2000. Bioclimatic variables are directly related to the physiological aspects of the growth of the species under study. The values of these variables do not depend on the timing of a particular state of growth. The variable "soil type" 
was downloaded from the FAO global harmonized soil database (FAO, 2012). In addition, the bioclimatic variable Aridity Index was created from the evapotranspiration (ETP) and annual rainfall (Bio12) variables obtained from the Africlim website, using the spatial analysis tools of ArcGIS, version 10.1. All environmental data were taken at a resolution of 2.5 minutes (approximately $4.64 \mathrm{~km} \times$ $4.64 \mathrm{~km}$ grid at the equator) and prepared in ASCII format with ArcGIS 10.1 software.

\subsection{Modelling Method}

In this study, the Maximum Entropy (Maxent) method was used. This method represents one of the most powerful techniques used to estimate the probability of occurrence of a species in a region based on the corresponding environmental conditions (Phillips et al., 2006, 2017). This method combines observed occurrence data of one or more species with current bioclimatic characteristics at observation points to generate: 1) A global map of the species' potential habitats in the study area; 2) A global map of the future distribution of its favourable habitats according to climate projections made by general circulation models for the area. Maxent is a statistical machine learning method that estimates the most uniform distribution of occurrence points within the study area, considering the constraint that, the average value of each environmental variable under this estimated distribution is equal to its empirical mean. Recent development of the approach has shown that it is a modelling technique based on heterogeneous Poisson point processes, called PPI (Warton \& Shepherd, 2010; Fithian \& Hastie, 2013). This approach leads to an estimate of the relative abundance of the species with respect to environmental climatic conditions. The resulting relative probability map was then transformed into a presence probability map using an appropriate function; cloglog's was used in this study (Phillips et al., 2017).

\subsection{Model Calibration and Validation}

The selection of environmental variables included in the potential distribution model of $V$. paradoxa species was based on correlation analysis between bioclimatic variables as well as knowledge of the ecology of the species (Austin, 2012). For this purpose, we used the ENMtools program (Warren et al., 2010) to analyse the correlation between variables in order to keep the variables with an absolute correlation coefficient less than or equal to 0.80 (Elith et al., 2010), after the evaluation of their effects in a model taking into account all bioclimatic variables.

The Jackknife test was performed on the selected bioclimatic variables to determine which ones showed the best contributions. The $V$. paradoxa distribution models were calibrated with MaxEnt, version 3.3.4 using the iterative five-fold repeated cross validation method. This is a validation method that involves partitioning the occurrence dataset into five parts, four of which are used for calibration while the remaining part is used for evaluation. The process was iterated 
until all five parts have been used for model evaluation. The performance of the models was assessed by the AUC (Area under the ROC Curve) statistic. A model with an AUC value equal to 0.5 shows that it is not better than a random prediction while a value close to 1 (AUC $\geq 0.75$ ) indicates a very good model performance. Considering some criticisms made by ecologists on the AUC index, which is thought to Area Under the ROC Curve, we had alternatively calculated the TSS (True Skill Statistics) which is a statistic that measures the ability of the model to detect true presences (sensitivity) and false absences (specificity) (Allouche et al., 2006). A TSS value greater than 0.70 indicates good model performance in predicting species distribution. The results obtained with MaxEnt were imported into ArcGIS 10.1 software to map the habitats favourable for the species for both current and future climate conditions (horizon 2055) according to each of the two scenarios considered, the RCP 4.5 and RCP 8.5 . The probability distribution of occurrence generated by MaxEnt was used as an indicator of the quality of favourable habitats for $V$. paradoxa. In addition, a gap analysis of favourable habitats within Benin's protected area network was performed by overlaying the map of Benin's national protected area network with maps of favourable habitats. Finally, the ArcGIS spatial analysis tool was used to spatialize the dynamics of favourable areas under current and future conditions.

\section{Results}

\subsection{Contribution of Environmental Variables and Model Performance}

The Jackknife test (Figure 2) and the variable contribution analysis (Table 1) identified six variables out of the 21 bioclimatic variables studied as contributing to the spatial distribution of $V$. paradoxa. These were the aridity index (Arid), the iso-thermality (Bio3), the temperature seasonality (Bio4), the minimum temperature of the coldest period (Bio 6), the rainfall of the driest month (Bio14) and the rainfall of the driest quarter (Bio17). The aridity index (Arid, 38.7\%) contributed the most to the development of the model, followed by the minimum temperature of the coldest period (Bio6, 26.3\%) and the rainfall of the driest quarter (Bio17, 15.6\%). Based on the Jackknife test, the aridity index yielded

Table 1. Contribution of environmental and bioclimatic variables to the distribution of favourable shea trees' habitats in Benin.

\begin{tabular}{ccc}
\hline Codes & Variable name & Contribution (\%) \\
\hline Arid & Aridity Index & $38.7 \%$ \\
Bio6 & Minimum temperature of the coldest period & $26.3 \%$ \\
Bio17 & Precipitation of the driest quarter & $15.6 \%$ \\
Bio4 & Seasonality of temperature (Coefficient of variation) & $11 \%$ \\
Bio3 & Iso-thermality & $6.1 \%$ \\
Bio14 & Precipitation of the driest period & $2.3 \%$ \\
\hline
\end{tabular}




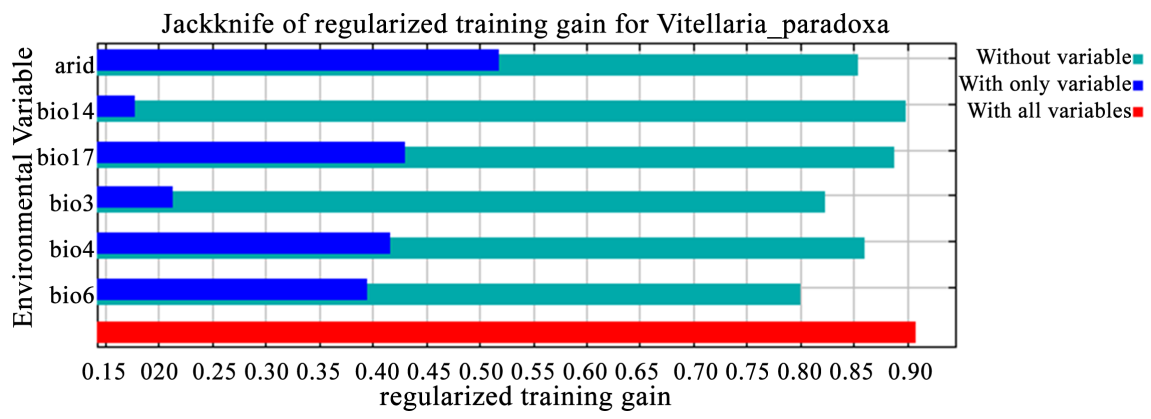

Figure 2. Result of the Jackknife test on the contribution of the bioclimatic variables to the distribution pattern of favourable shea trees' habitats in Benin.

the highest information gain when used alone in the model building, while the minimum temperature of the coldest period induced the highest information loss when omitted from the models (Figure 2). This means that the aridity index contains more useful information than the other variables, while the minimum temperature of the coldest period has most of the information that is absent in the other environmental variables. The average AUC value was equal to $0.86 \pm$ 0.002 , thus indicating that the models' predictions were better than a random prediction. The TSS value was $0.71 \pm 0.006$ indicating a good ability of the models to predict the distribution of $V$. paradoxa.

Figure 3 shows the maximum response curves for the six bioclimatic variables most influential on $V$. paradoxa distribution. The highest probability of $V \cdot$ paradoxa occurrence was obtained in areas where the aridity index was equal to 2 . The suitable site decreased above 2.2 and decreases sharply before 1.8 (Figure 3(a)). $V$. paradoxa was found to prefer areas where the minimum temperature of the coldest period was between $16.2^{\circ} \mathrm{C}$ and $17^{\circ} \mathrm{C}$. Above $17^{\circ} \mathrm{C}$, the probability of occurrence decreased sharply (Figure 3(b)). V. paradoxa was present in areas where rainfall of the driest quarter was between 10 and $50 \mathrm{~mm}$, after which the probability of occurrence also decreased sharply before stabilizing above 100 $\mathrm{mm}$ (Figure $3(\mathrm{c})$ ). Also, the seasonality of the optimum temperature of $V \cdot p a$ radoxa was between 22 and $25^{\circ} \mathrm{C}$. Above $27.5^{\circ} \mathrm{C}$, the probability of occurrence decreased sharply (Figure $3(\mathrm{~d})$ ). Then, $V$. paradoxa presented the optimal isotherm between 675 and 700 , above 700 the probability of occurrence stabilized (Figure $3(\mathrm{e})$ ). Finally, $V$. paradoxa occurred in areas where the optimum rainfall for the driest period was between -20 and $0 \mathrm{~mm}$. Below $-5 \mathrm{~mm}$ there was a decrease in the probability of occurrence then an increase from $0 \mathrm{~mm}$ and stabilized at $18 \mathrm{~mm}$.

\subsection{Current and Future Distribution of Favourable Habitats for Shea Tree Cultivation in Benin}

The results of the modelling indicated a distribution area of $94,816.36 \mathrm{~km}^{2}$, that is $80.58 \%$ of the Beninese national territory, which are currently very favourable for the cultivation and conservation of shea tree in Benin. With the bioclimatic projections of the MaxEnt model under the RCP 4.5 scenario, $V$. paradoxa will 


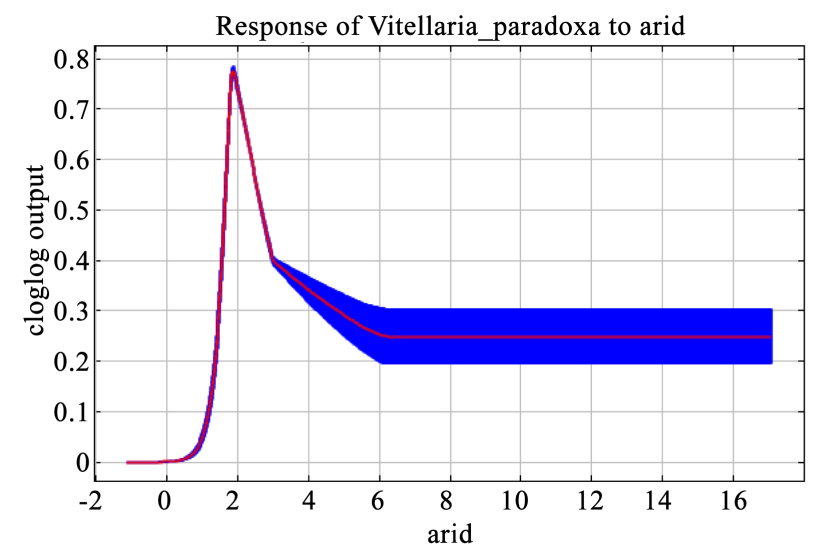

(a)

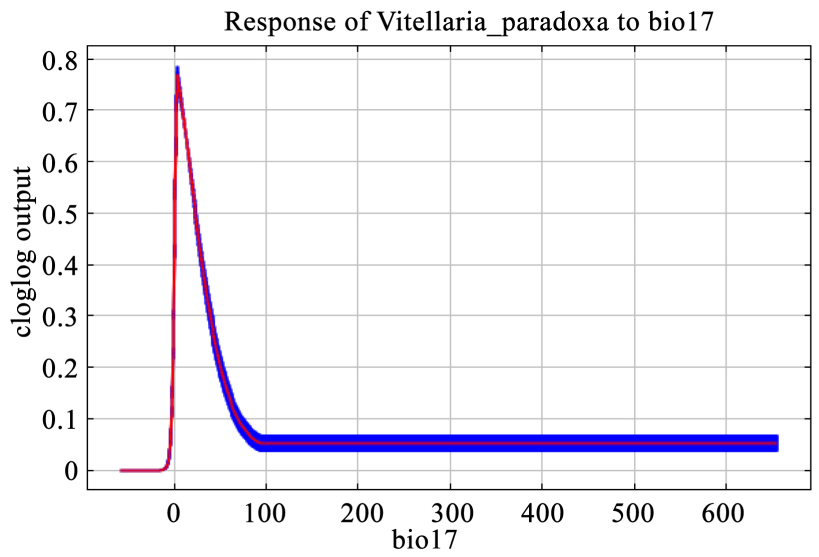

(c)

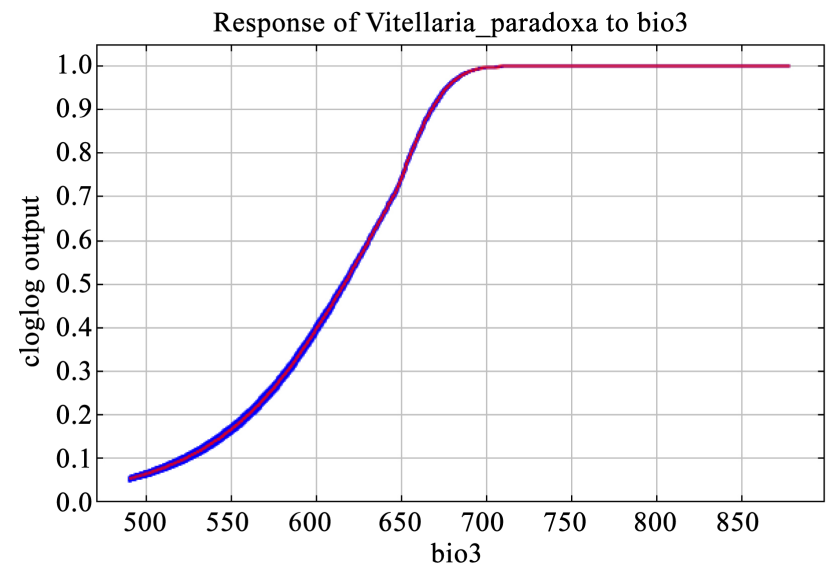

(e)

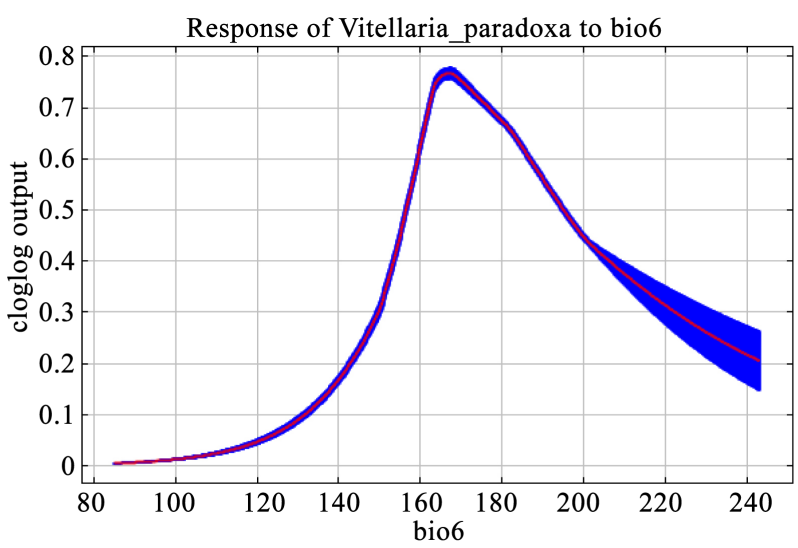

(b)

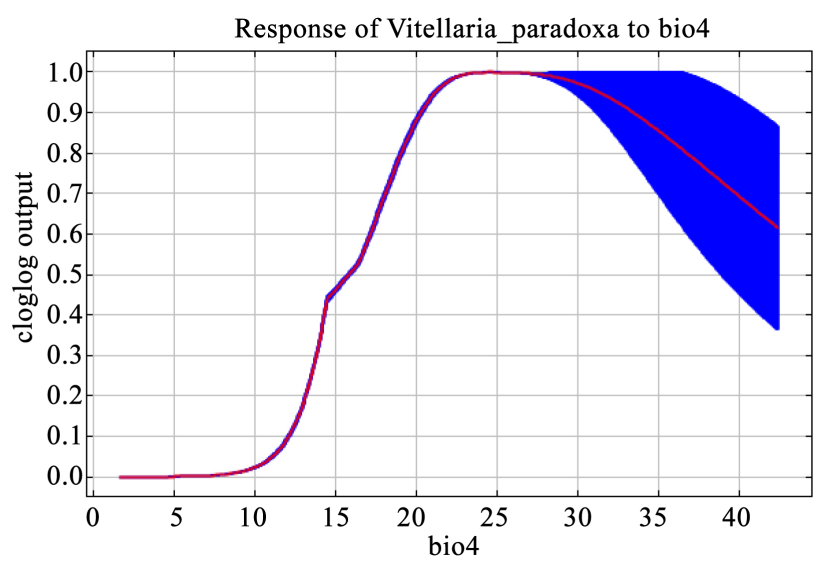

(d)

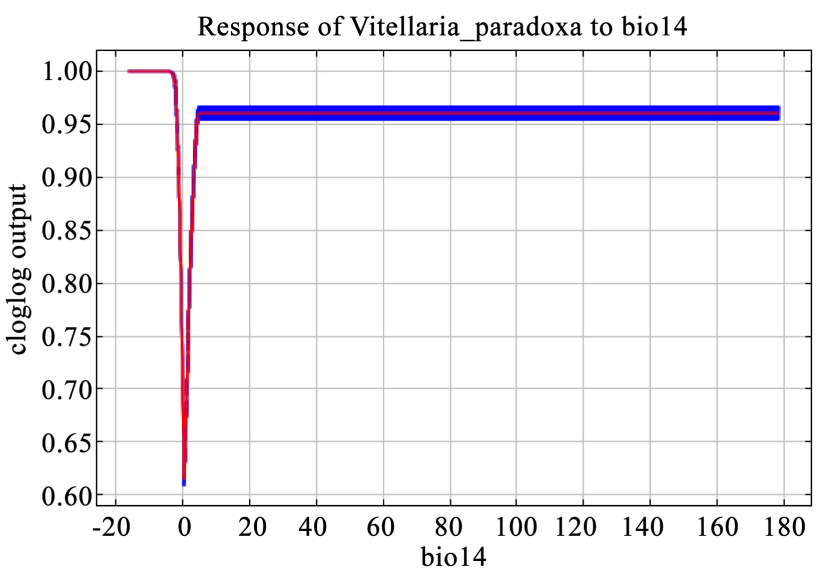

(f)

Figure 3. Response curves for variables (a) Aridity factor; (b) Minimum temperature of the coldest period in $1^{\circ} \mathrm{C}-10^{\circ} \mathrm{C}$; (c) Rainfall of the driest quarter in $1-10 \mathrm{~mm}$; (d) Temperature seasonality (Coefficient of variation); (e) Iso-thermality; (f) Rainfall of the driest period in $1-10 \mathrm{~mm}$.

lose nearly $14.33 \%$ of its currently very favourable habitats by the year 2055 (Figure 4). The same scenario also projected an increase of nearly $67 \%$ and $54 \%$, respectively, in moderately and poorly favourable, habitats for shea conservation by 2055. Both RCP 8.5 and RCP 4.5 scenarios projected similar trends by 2055. Considering the RCP $8.5, V$. paradoxa will lose nearly $18.4 \%$ of the current 


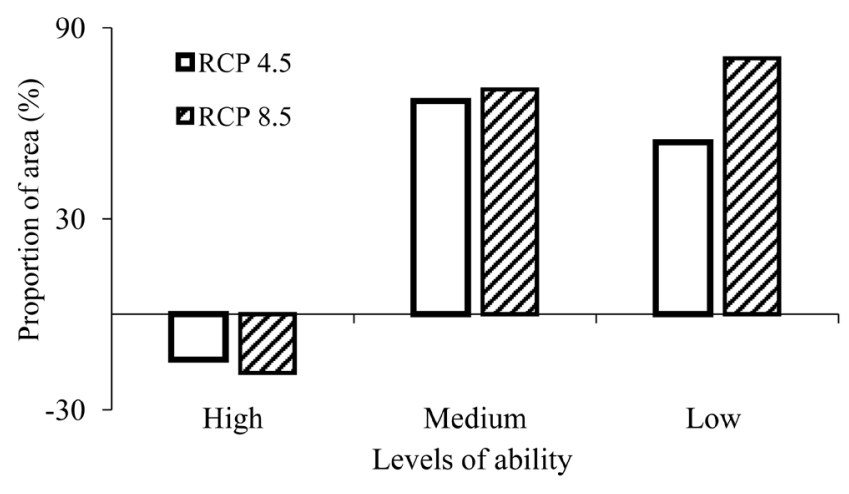

Figure 4. Rate of change of shea tree suitability levels in parklands.

habitats highly favourable by 2055 (Figure 4). Still under this scenario, it is also noticed respective increases of nearly $70 \%$ and $80 \%$ of the habitats that are moderately and poorly favourable for shea conservation, essentially at the expense of habitats that are currently very favourable. In sum, the scenarios projected a loss of areas currently highly favourable for shea tree cultivation and conservation by expanding areas of medium and low favourability in 2055 (Figure 5).

\subsection{Current and Future Distribution of Favourable Habitats for Shea Tree Conservation in the Protected Area Network}

The results of the modelling generated an area of $22,153.96 \mathrm{~km}^{2}$, representing 79.52\% of Benin Protected Area network, that is currently highly favourable for shea tree cultivation and conservation in Benin. With the bioclimatic projections of the MaxEnt model considering the RCP 4.5 scenario, $V$. paradoxa will lose nearly $26.3 \%$ of the habitats that are currently highly favourable by 2055 (Figure 6). The same scenario also projected an increase of nearly $781.25 \%$ of the habitats that are weakly favourable to the species by 2055 , essentially by conversion of habitats that are currently highly favourable. The RCP 8.5 scenario presents a loss of currently very favourable habitats by 2055 with a loss of $29.9 \%$ of the habitats that are very favourable for shea tree cultivation and conservation. This is due to the conversion of $9.87 \%$ and $890.66 \%$ of habitats into moderately favourable and very poorly favourable habitats respectively (Figure 6). In essence, all scenarios to 2055 correspond to a loss of currently highly favourable areas in favour of moderately and poorly favourable habitats (Figure 7).

\section{Discussion}

\subsection{Model Reliability and Methodological Limitations}

Predictive models are still powerful tools in decision making for the conservation and domestication of species (Schwartz, 2012). These models make it possible to statistically link the observed distribution of a species for a given period of time to the different ecological and climatic factors likely to structure it is observed range (Piedallu, 2009). Thus, ecological niche modelling has often been cited as a powerful tool for mapping the current and future distribution of 


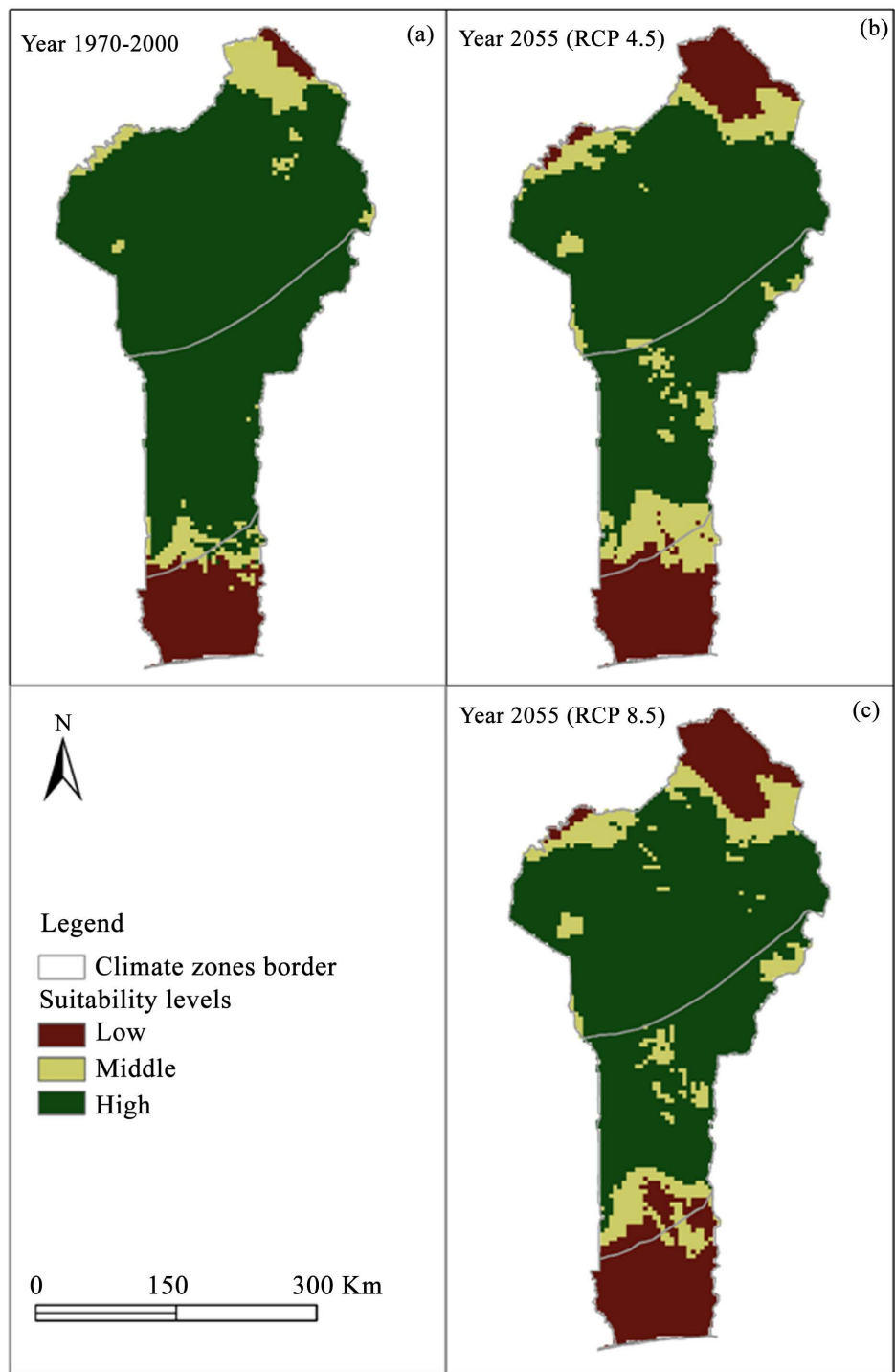

Figure 5. Spatial distribution of Vitellaria paradoxa over the period of 1970-2000 (a) and predicted distribution under the RCP 4.5 (b) and 8.5 (c) scenarios in Benin by 2055.

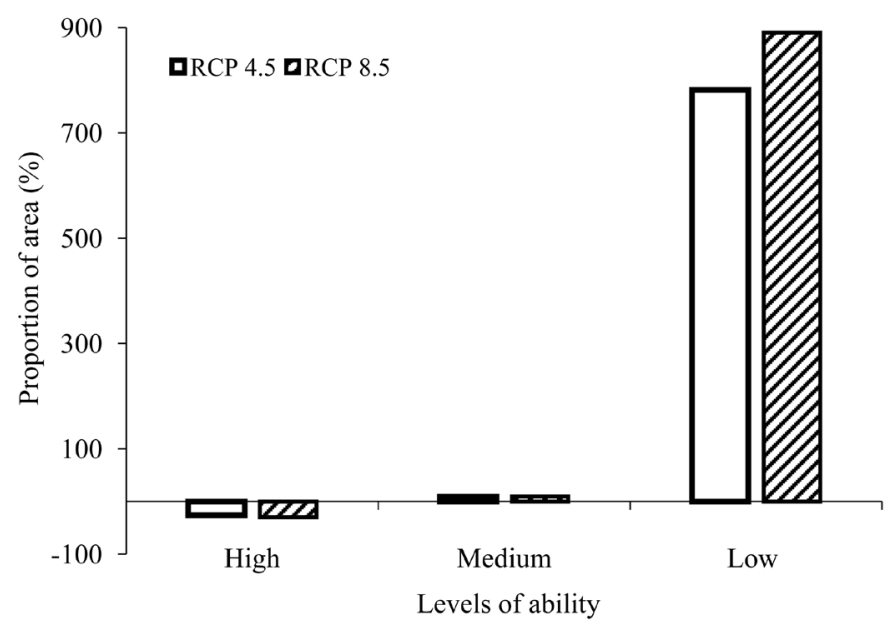

Figure 6. Rate of change of shea tree suitability levels in the shea parks. 


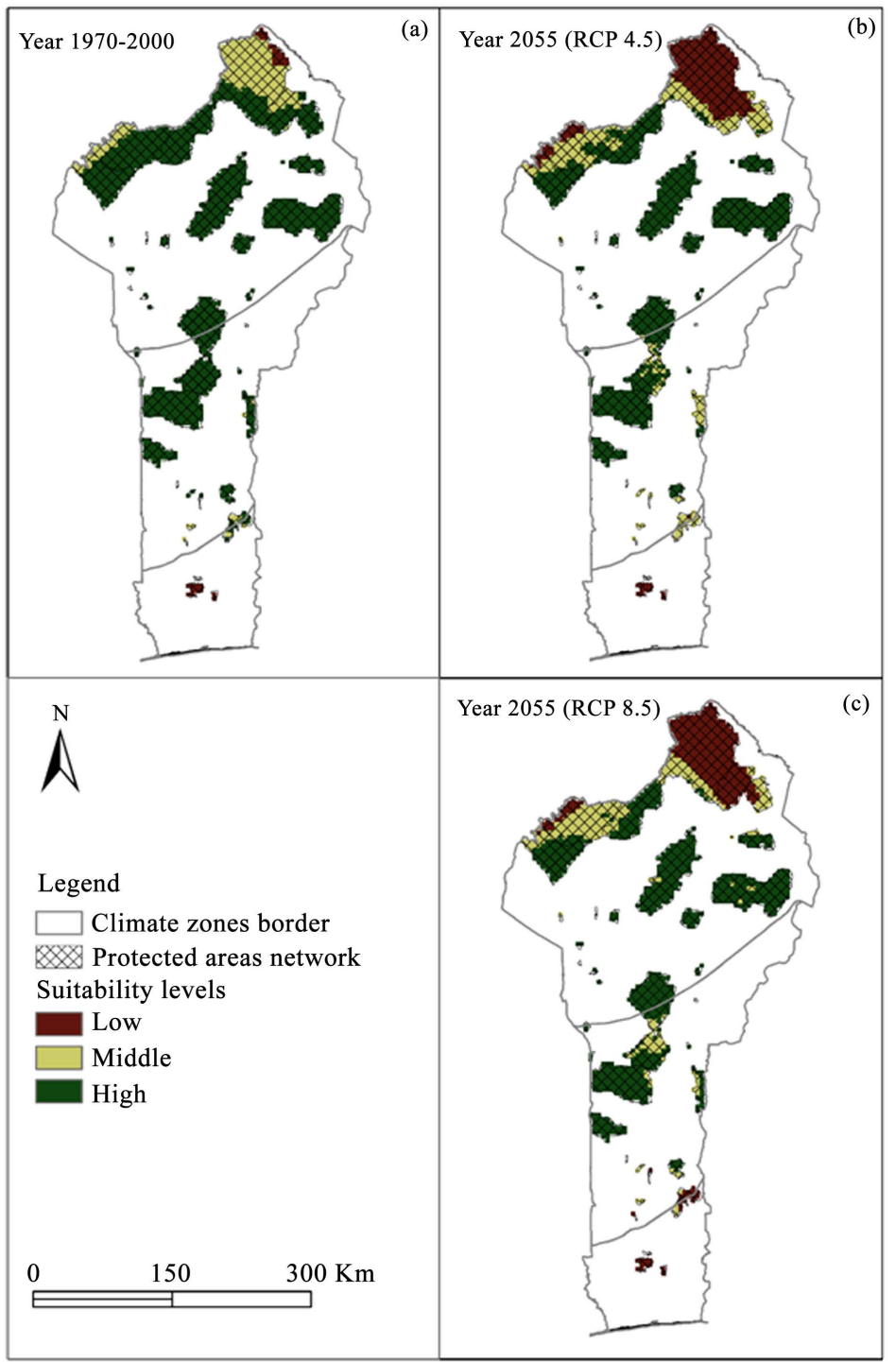

Figure 7. Spatial distribution of Vitellaria paradoxa in the protected areas considering (a) 1970-2000 period and predicted distribution; (b) Considering the RCP 4.5 Scenario by; (c) Considering the RCP 8.5 scenario by 2055 .

species and projecting the impact of climate change on their distribution (Fandohan et al., 2013; Ayihouenou et al., 2016; Fachola et al., 2019). Within the framework of the present study, this model enabled a prediction of favorable areas to the presence of shea tree in Benin by 2055. The quality of this prediction model was evaluated through the AUC. The AUC value obtained for the model was higher than 0.8 , which indicates a good capacity of the model to predict suitable habitats for $V$. paradoxa under climate change scenarios (Araújo et al., 2005). Research work carried out by (White, 1983) showed that the earliest descriptions of shea tree occurrence are in West Africa. These models provided very crucial bioclimatic information for decision-making, especially for identifying new areas potentially favourable for cultivation (Cuni-Sanchez et al., 2010) or for the conservation of a given species (Schwartz, 2012). However, there are 
some uncertainties related to the models used, including difficulties in parameterizing ecological interactions, individual idiosyncratic responses of species to climate change, species-specific release limitations, the plasticity of physiological limits and adaptive responses of the releasing agents (Fandohan et al., 2013; Dotchamou et al., 2016).

\subsection{Environmental Parameters Determining the Spatial Distribution of Shea Tree in Benin}

The results of the present study showed that six environmental variables contributed to the spatial distribution of $V$. paradoxa. These variables include aridity index, iso-thermality, seasonality of temperature, minimum temperature of the coldest period, rainfall of the driest period and rainfall of the driest quarter. The aridity index is the factor that had the strongest contribution in the development of the model. The aridity index is a variable related to evapotranspiration and rainfall that influences the species distribution environment (Phillips et al., 2017). The aridity of the area then influenced the spatial distribution of shea tree. This corroborates findings of (Hall et al., 1996) who noted that shea tree grows in arid and semi-arid regions where rainfall amounts vary between 400 and $1500 \mathrm{~mm}$. This explains the fact that densities of shea trees are very high in the Sudanian zone of Benin compared to the humid zone. Also, it was noticed that shea tree tolerates prolonged drought period up to eight months (Vermilye, 2004). Furthermore, temperature and rainfall were climatic factors that induce the distribution of shea tree in Benin.

Climatic variables therefore explain the distribution of shea tree in Benin. These results are consistent with those obtained by (Dimobe et al., 2020) on shea tree in Burkina Faso and (Fandohan et al., 2013) on tamarind in Benin. Indeed, the variables Seasonality of temperature (bio4) and Iso-thermality (bio3) related to light and heat variation and the variables aridity; Rainfall of the driest quarter (bio14), Rainfall of the driest period (bio17) related to water variation that had an effect on the plant physiological development and the presence of a species in a given location (O’Donnell \& Ignizio, 2012; Hatfield \& Prueger, 2015). Light deficiency affects the level of regeneration and diameter of the shea tree trunk (Gnanglè et al., 2011; Ouoba et al., 2020). Regarding the temperature, shea tree is a very sensitive species to temperature variations. (Boffa, 2000; Avaligbé et al., 2021) have shown that temperature variation during flowering and fruiting of shea tree has an influence on the level of productivity. To counteract the influence of climatic factors on shea's range, conservation strategies must be implemented like grafting and cuttings or development of climate-resistant cultivars to increase the productivity of shea tree (Venturini et al., 2016).

\subsection{Conservation Strategies for Shea Tree in Benin in the Context of Climate Change}

In Benin, climate projections for the year 2055, according to the two scenarios studied, showed that the habitats that are weakly and moderately favourable for 
V. Paradoxa would expand. This situation could be explained by the fact that, climate variation could modify habitats favourable to plant species as reported by (Gouwakinnou, 2013) on Sclerocarya birrea (Anacardiaceae), (Fandohan et al., 2013) on Tamarindus indica (Caesalpiniaceae) and (Ayihouenou et al., 2016) on Parkia biglobosa (Mimosaceae). As for protected areas, they are reserve areas that promote biodiversity conservation (Houinato et al., 2001). As for protected areas, the results showed that $79.52 \%$ of the surface area of the entire network of protected areas in Benin is currently very favourable for shea tree conservation. These areas then constitute reserves that further promote biodiversity conservation (Houinato et al., 2001).

It is often reported that species present in a protected area has a high probability of survival without further intervention and management measures once the protected area is properly managed (Heywood, 2008; Agbo et al., 2017). Evaluation of the relationship between $V$. paradoxa distribution and protected areas showed good potential for protected areas for shea tree conservation. The model projected for all climate scenarios an increase in medium and low shea conservation habitats in the protected areas. The increases will be very high for the poorly favourable habitats. These results strengthened the potential of the in situ conservation approach to maintain the species. (Fandohan et al., 2010) and (Gouwakinnou, 2011) justified the relative effectiveness of protected areas in conserving some indigenous fruit trees (Tamarindus indica L. and Sclerocarya birrea (A.Rich.) Hochst) in sub-Saharan Africa. Furthermore, the protected areas are nowadays threatened by anthropic pressure (logging, fossil fuels). It is therefore necessary to consider the prospects for shea tree conservation. Also, in areas suitable for shea tree growing and conservation, the establishment of shea stands by vegetative propagation (cuttings and grafting) would be an alternative to not only increase shea stands to colonize new favourable habitats, but also to strengthen and intensify farmers' current traditional cropping practices (e.g. intercropping of shea with annual crops) in their seek to mitigate climate change effect.

\section{Conclusion}

The present research revealed that the spatial distribution of shea was modulated by six environmental variables: aridity index, iso-thermality, temperature seasonality, minimum temperature of the coldest period, rainfall of the driest month and rainfall of the driest quarter. The three main environmental and bioecological variables that determine the ecological optimum of shea tree distribution were aridity index, iso-thermality, and temperature seasonality, which represented $80 \%$ of the distribution of favourable shea habitats in Benin. The distribution area of shea was thus intimately linked to climatic variations. Projections showed that the area of distribution of shea trees in very favourable habitats will progressively decrease in most of the country's climatic zones under the two climate scenarios (RCP 4.5 and RCP 8.5). The decrease was maximal under the RCP 8.5 
scenario. The preservation of individuals species by implementing good cropping practices and the establishment of shea stands in favourable areas through rapid vegetative propagation techniques were suggested for sustainable conservation of this tree of great socioeconomic and ecological importance for the local population

\section{Conflicts of Interest}

The authors declare no conflicts of interest regarding the publication of this paper.

\section{References}

Adjahossou, S. G. C., Gouwakinnou, G. N., Houéhanou, D. T., Sode, A. I., Yaoitcha, A. S., Houinato, M. R. B., \& Sinsin, B. (2016). Efficacité des aires protégées dans la conservation d'habitats favorables prioritaires de ligneux de valeur au Bénin. Bois Forêts des Tropiques, 328, 67-76. https://doi.org/10.19182/bft2016.328.a31303

Agbo, R. I., Missihoun, A. A., Vihotogbé, R., Assogbadjo, E. A., Ahanhanzo, C., \& Agbangla, C. (2017). Impacts des usages traditionnels sur la vulnérabilité de Detarium microcarpum Guill. \& Perr. (Caesalpiniaceae) dans le district phytogéographique Zou au Bénin (en Afrique de l'Ouest). International Journal of Biological Chemical Sciences, 11, 730-743. https://doi.org/10.4314/ijbcs.v11i2.16

Aleza, K., Villamor, G. B., Nyarko, B. K., Wala, K., \& Akpagana, K. (2018). Shea (Vitellaria paradoxa Gaertn C. F.) Fruit Yield Assessment and Management by Farm Households in the Atacora District of Benin. PLoS ONE, 13, e0190234.

https://doi.org/10.1371/journal.pone.0190234

Allouche, O., Tsoar, A., \& Kadmon, R. (2006) Assessing the Accuracy of Species Distribution Models: Prevalence, Kappa and the True Skill Statistic (TSS). Journal of Applied Ecology, 43, 1223-1232. https://doi.org/10.1111/j.1365-2664.2006.01214.x

Araújo, M. B., Pearson, R. G., Thuiller, W., \& Erhard, M. (2005). Validation of Species-Climate Impact Models under Climate change. Global Change Biology, 9, 1504-1513. https://doi.org/10.1111/j.1365-2486.2005.01000.x

Arbonnier, M. (2002). Arbres, Arbustes et Lianes Des Zones Sèches d'Afrique de l'Ouest (2nd Ed., p. 574). Muséum national d'Histoire naturelle.

Austin, P. C. (2012). Generating Survival Times to Simulate Cox Proportional Hazards Models with Time-Varying Covariates. Statistics in Medicine, 31, 3946-3958. https://doi.org/10.1002/sim.5452

Avaligbé, Y. J. F., Gnanglè, C. P., Yabi, I., Bello, O. D., Ahoton, E. L., \& Saïdou, A. (2021). Tendances climatiques, perceptions des gestionnaires des parcs à karité sur la productivité du karité ( Vitellaria paradoxa) au Bénin. Journal of Apply, Biosciences, 157, 16237-16253.

Ayihouenou, E. B., Fandohan, A. B., Sode, A. I., Gouwakinnou, N. G., \& Djossa, A. B. (2016). Biogéographie du néré (Parkia biglobosa (Jack.) R Br. ex. Don.) sous les conditions environnementales actuelles et futures au Bénin. Bulletin de la Recherche Agronomique du Bénin (BRAB), 93-108.

Boffa, J. (2000) West African Agroforestry Parklands: Keys to Conservation and Sustainable Management. Unasylva, 51, 11-17

Boffa, J. M. (2015). Opportunities and Challenges in the Improvement of the Shea (Vitellaria paradoxa) Resource and Its Management (76 p). World Agroforestry Centre.

Busby, J. W., Smith, T. G., White, K. L., \& Strange, S. M. (2012). Locating Climate Inse- 
curity: Where Are the Most Vulnerable Places in Africa? In J. Scheffran, M. Brzoska, H. Brauch, P. Link, \& J. Schilling (Eds.), Climate Change, Human Security and Violent Conflict (pp. 463-511). Springer.

https://doi.org/10.1007/978-3-642-28626-1_23

Castro, A. J., Martín-Lopez, B., Lopez, E., Plieninger, T., Alcaraz-Segura, D., Vaughn, C., \& Cabello, J. (2015). Do Protected Areas Networks Ensure the Supply of Ecosystem Services? Spatial Patterns of two Nature Reserve Systems in Semi-Arid Spain. Apply Geography, 60, 1-9. https://doi.org/10.1016/j.apgeog.2015.02.012

Cuni-Sanchez, A. C., Osborne, P. E., \& Haq, N. (2010). Identifying the Global Potential for Baobab Tree Cultivation Using Ecological Niche Modelling. Agroforestry System, 80, 191-201. https://doi.org/10.1007/s10457-010-9282-2

Diarrassouba, N., Koffi, K. E., N’Guessan, K. A., Patrick, V., \& Sangare, A. (2008). Connaissances locales et leur utilisation dans la gestion des parcs à karité en Côte d'Ivoire. Afrika Focus, 1, 77-96. https://doi.org/10.1163/2031356X-02101007

Dimobe, K., Goetze, D., Ouédraogo, A., Mensah, S., Porembski, S., \& Thiombiano, A. (2019). Aboveground Biomass Allometric Equations and Carbon Content of the Shea Butter Tree (Vitellaria paradoxa C.F. Gaertn) Components in Sudanian Savannas (West Africa). Agroforestry System, 93, 1119-1132. https://doi.org/10.1007/s10457-018-0213-y

Dimobe, K., Ouédraogo, A., Ouédraogo, K., Goetze, D., Stein, K., Schmidt, M. et al. (2020). Climate Change Reduces the Distribution Area of the Shea Tree (Vitellaria paradoxa C.F. Gaertn.) in Burkina Faso. Journal of Arid Environments, 181, Article ID: 104237. https://doi.org/10.1016/j.jaridenv.2020.104237

Dotchamou, F. T., Atindogbe, G., Sode, A. I., \& Fonton, H. N. (2016). Density and Spatial Pattern of Parkia Biglobosa under Climate Change: The Case of Benin. Journal of Agriculture and Environment for International Development, 110, 173-194.

Elith, J., Kearney, M., \& Phillips, S. (2010). The Art of Modelling Range-Shifting Species. Methods in Ecology and Evolution, 1, 330-342. https://doi.org/10.1111/j.2041-210X.2010.00036.X

Elith, J., Phillips, S. J., Hastie, T., Dudik, M., Chee, Y. E., \& Yates, C. J. (2011). A Statistical Explanation of MaxEnt for Ecologists. Diversity and Distributions, 17, 43-57. https://doi.org/10.1111/j.1472-4642.2010.00725.x

Fachola, O. B., Lougbégnon, O. T., \& Agossou, N. (2019). Modélisation de la niche écologique de Parkia biglobosa (Jacq.) au Sud et au Centre du Bénin (Afrique de l'Ouest). Revue canadienne de géographie, 1, 19-25.

Fandohan, B., Assogbadjo, A. E., Glèlè Kakaï, R. L., \& Sinsin, B. (2010). Effectiveness of a Protected Areas Network in the Conservation of Tamarindus indica (Leguminosae-Caesalpinioideae) in Benin. African Journal of Ecology, 49, 40-50.

https://doi.org/10.1111/j.1365-2028.2010.01228.x

Fandohan, B., Gouwakinnou, G. N., Fonton, N. H., Sinsin, B., \& Liu, J. (2013). Impact des changements climatiques sur la répartition géographique des aires favorables à la culture et à la conservation des fruitiers sous-utilisés: Cas du tamarinier au Bénin. Biotechnologie, Agronomie, Société et Environnement, 17, 450-462.

Fithian, W., \& Hastie, T. (2013). Finite-Sample Equivalence in Statistical Models for Presence-Only Data. The Annals of Applied Statistics, 7, 1917-1939.

https://doi.org/10.1214/13-AOAS667

Food and Agriculture Organization of the United Nations (FAO) (1989). Arid Zone Forestry: A Guide for Field Technicians. Food and Agriculture Organization of the United Nations. 
Food and Agriculture Organization of the United Nations (FAO) (2012). Harmonized World SoilDatabase (Version 1.2). Food Agriculture Organization. http://webarchive.iiasa.ac.at/Research/LUC/External-World-soil-database/HTML/

Gbètoho, A. J., Aoudji, A. K. N., Roxburgh, L., \& Ganglo, J. C. (2017). Assessing the Suitability of Pioneer Species for Secondary Forest Restoration in Benin in the Context of Global Climate Change. Bois et Forêts des Tropiques, 332, 43-55.

https://doi.org/10.19182/bft2017.332.a31332

Gnanglè, C. P (2017). Le karité béninois: Entre promotion des femmes rurales et création durable de valeur ajoutée (115 p). Rapport d'étude. Projet d'Appui au Renforcement des Acteurs du Secteur Privé (PARASEP).

Gnanglè, P. C. (2005). Parcs à karité (Vitellaria paradoxa) (Gaertn. C. F.) (Sapotaceae) au Bénin: Importance socio-culturelle, caractérisations morphologique, structurale et régénération naturelle. Mémoire de DEA, Faculté des Sciences Agronomiques, Université d'Abomey-Calavi.

Gnanglè, P. C., GlèlèKakaï, R. L., Assogbadjo, A. E., Vodounon, S., Yabi, J. A., \& Sokpon, N. (2011). Tendances climatiques passées, modélisation, perceptions et adaptations locales au Bénin. Climatologie, 8, 26-40. https://doi.org/10.4267/climatologie.259

Gouwakinnou, G. N. (2013). Using Niche Modelling to Plan Conservation of an Indigenous Tree Species under Changing Climate: Example of Sclerocarya birrea in Benin, West Africa. Research and Development in sub-SaharanAfrica, 5, 1-8.

Gouwakinnou, N. G. (2011). Population Ecology, Uses and Conservation of Sclerocarya birrea (A. Rich) Hocchst. (Anacardiaceae) in Benin, West Africa. PhD Thesis, University of Abomey Calavi.

Hall, J. B., Aebischer, D. P., Tomlison, H. F., Osei-Amaning, E., \& Hindle, J. R. (1996). Vitellaria paradoxa: A Monograph. School of Agricultural and Forest Sciences, University of Wales.

Hatfield, J. L., \& Prueger, J. H. (2015). Temperature Extremes: Effect on Plant Growth and Development. Weather and Climate Extremes, 10, 4-10. https://doi.org/10.1016/j.wace.2015.08.001

Heywood, V. H. (2008) Challenges of in Situ Conservation of Crop Wild Relatives. Turkish Journal of Botany, 32, 421-432.

Houinato, M., Sinsin, B., \& Lejoly, J. (2001) Impact des feux de brousse sur la dynamique des communautés végétales dans la forêt de Bassila (Bénin). Acta Botanica Gallica, 148, 237-251. https://doi.org/10.1080/12538078.2001.10515891

Idohou, R., Assogbadjo, A. E., Glèlè Kakaï, R., \& Peterson, A. T. (2017). Spatiotemporal Dynamic of Suitable Areas for Species Conservation in West Africa: Eight Economically Important Wild Palms under Present and Future Climates. Agroforest System, 91, 527-540. https://doi.org/10.1007/s10457-016-9955-6

International Union for Conservation of Nature (IUCN) (2019). The IUCN Red List of Threatened Species. Version 2019-2. https://www.iucnredlist.org

Jasaw, G. S., Saito, O., \& Takeuchi, K. (2015). Shea (Vitellaria paradoxa) Butter Production and Resource Use by Urban and Rural Processors in Northern Ghana. Sustainability, 7, 3592-3614. https://doi.org/10.3390/su7043592

Jonsson, K., Ong, C. K., \& Odongos, J. C. W. (1999). Influence of Scattered néré and karité on Microclimate, Soil Fertility and Millet Yield in Burkina Faso. Experimental Agriculture, 35, 39-53. https://doi.org/10.1017/S0014479799001039

Lamien, N., Ouédraogo, S. J., Diallo, O. B., \& Guinko, S. (2004). Productivité fruitière du karité (Vitellaria paradoxa) dans les parcs agroforestiers traditionnels au Burkina Faso. 
Fruits, 59, 423-429. https://doi.org/10.1051/fruits:2005004

Leakey, R. R. B. (2010). Should We Be Growing More Trees on Farms to Enhance the Sustainability of Agriculture and Increase Resilience to Climate Change? Special Report. International Society of Tropical Foresters News, United States Agency for International Development.

Lovett, P. (2004). The Shea Butter Value Chain: Production, Transformation and Marketing in West Africa (pp. 2). West Africa Trade Hub (WATH).

Lovett, P. N., \& Haq, N (2000). Evidence for Anthropic Selection of the Sheanut Tree (Vitellaria paradoxa). Agroforestry System, 48, 273-288.

https://doi.org/10.1023/A:1006379217851

Marshall, A. R., Platts, P. J., Gereau, R. E., Kindeketa, W., Kang'ethe, S., \& Marchant, R. (2012). The Genus Acacia (Fabaceae) in East Africa: Distribution, Diversity and the Protected Area Network. Plant Ecology and Evolution, 145, 289-301.

https://doi.org/10.5091/plecevo.2012.597

Nde, B. D., Mohammed, M. A., César, K., \& Zéphirin, M. (2014). Production Zones and Systems, Markets, Benefits and Constraints of Shea (Vitellaria paradoxa G.) Butter Processing. Oilseeds \& Fats Crops Lipids, 21, Article No. D206. https://doi.org/10.1051/ocl/2013045

Neuenschwander, P., Sinsin, B., \& Goergen, G (2011). Protection de la Nature en Afrique de l'Ouest: Une Liste Rouge pour le Bénin. Nature Conservation in West Africa: Red List for Benin (365 p). International Institute of Tropical Agriculture.

O’Donnell, M. S., \& Ignizio, D. A (2012). Bioclimatic Predictors for Supporting Ecological Applications in the Conterminous United States (pp. 1-10). Data Series No. 691, U.S. Geological Survey. https://doi.org/10.3133/ds691

Ouoba, Y. H., Bastide, B., Kaboré, A., Yaméogo-Gaméné, S. C., \& Belem, B. (2020). Régénération assistée du karité (Vitellaria paradoxa C. F. Gaertn.) dans les parcs agroforestiers au Burkina Faso. European Scientific Journal, 16, 23-28. https://doi.org/10.19044/esj.2020.v16n40p23

Padonou, A. E., Teka, O., Bachmann, Y., Schmidt, M., Lykke, A. M., \& Sinsin, B. (2015). Using Species Distribution Models to Select Species Resistant to Climate Change for Ecological Restoration of Bowé in West Africa. African Journal of Ecology, 53, 83-92. https://doi.org/10.1111/aje.12205

Pearson, G. R., Raxworth, J. C., Nakamura, M., \& Peterson, A. T. (2007). Predicting Species Distributions from Small Numbers of Occurrence Records: A Test Case Using Cryptic Geckos in Madagascar. Journal of Biogeography, 34, 102-117. https://doi.org/10.1111/j.1365-2699.2006.01594.x

Peterson, A. T., Soberón, J., Pearson, R. G., Anderson, R. P., Nakamura, M., MartinezMeyer, E., \& Araújo, M. B. (2011). Ecological Niches and Geographical Distributions. Princeton University Press.

Phillips, S. J., Anderson, R. P., \& Schapire, R. E. (2006). Maximum Entropy Modeling of Species Geographic Distributions. Ecological Modelling, 190, 231-259. https://doi.org/10.1016/j.ecolmodel.2005.03.026

Phillips, S. J., Anderson, R. P., Dudík, M., \& Schapire, R. E. (2017). Opening the Black Box: An Open-Source Release of Maxent. Ecography, 40, 887-893. https://doi.org/10.1111/ecog.03049

Piedallu, C., Perez, V., Gégout, J. C., Lebourgeois, F., \& Bertrand, R. (2009). Impact potentiel du changement climatique sur la distribution de l'Épicéa, du Sapin, du Hêtre et du Chêne sessile en France. Revue forestière française, No. 6, 567-593.

https://doi.org/10.4267/2042/32924 
Platts, P. J., Omeny, P. A., \& Marchant, R. (2015). AFRICLIM: High-Resolution Climate Projections for Ecological Applications in Africa. African Journal of Ecology, 53, 103-108. https://doi.org/10.1111/aje.12180

Saïdou, A., Dossa, A. F. E., Gnanglè, P. C., Balogoun, I., \& Aho, N. (2012). Evaluation du stock de carbone dans les systemes agroforestiers à karité (Vitellaria paradoxa C.F. Gaertn.) et à néré (Parkia biglobosa Jacq. G. Don) en zone Soudanienne du Bénin. International Journal of Biological and Chemical Sciences, 2066-2082.

Salako, K. V., Kénou, C., Dainou, K., Assogbadjo, E. A., \& Glele-Kakaï, L. R. (2018). Impacts of Land Use Types on Spatial Patterns and Neighbourhood Distance of the Agroforestry Palm Borassus aethiopum Mart. in Two Climatic Regions in Benin, West Africa. Agroforestry System, 93, 1057-1071.

Sanon, Z. (2009). Fonctionnement physiologique du karité (Vitellaria paradoxa Gaertn. F Hepper. Sapotaceae) sous différents régimes d'eau. Mémoire de fin de cycle. Universite Polytechnique de Bobo-Dioulasso. 76 p.

Schwartz, M. W. (2012). Using Niche Models with Climate Projections to Inform Conservation Management Decisions. Biological Conservation, 155, 149-156. https://doi.org/10.1016/j.biocon.2012.06.011

Traoré, K. B. (2003). Le parc à karité: Sa contribution à la durabilité de l'agrosystème. Cas d'une toposéquence à Konobougou (Mali-Sud). Thèse de doctorat, Montpellier. Centre de coopération Internationale en Recherche Agronomique pour le Développement.

Venturini, S., Haworth, A., Coudel, N., Alonso, E. J., \& Simonet, C. (2016). Cultivating Climate Resilience: The Shea Value Chain (pp. 1-68). Working Paper, Building Resilience and Adaptation to Climate Extremes and Disasters. http://www.braced.org

Vermilye, K. L. (2004). Vitellaria paradoxa and the Feasibility of a Shea Butter Project in the North of Cameroon. MSc Paper, State University of New York at Geneseo.

Warren, D. L., Glor, R. E., \& Turelli, M. (2010). ENMTools: A Toolbox for Comparative Studies of Environmental Niche Models. Ecography, 33, 607-611. https://doi.org/10.1111/j.1600-0587.2009.06142.x

Warton, D. I., \& Shepherd, L. C. (2010). Poisson Point Process Models Solve the "Pseudo-Absence Problem" for Presence-Only Data in Ecology. The Annals of Applied Statistics, 4, 1383-1402. https://doi.org/10.1214/10-AOAS331

White, F. (1983). The Vegetation of Africa. A Descriptive Memoir to Accompany the Unesco/AETFAT/UNSO Vegetationmap of Africa. Natural Resources Research.

World Agroforestry Centre (2008). Transforming Lives and Landscapes. Strategy 20082015. World Agroforestry Centre

Yabi, I. (2008). Etude de l'agroforesterie à base d'anacardier et des contraintes climatiques à son développement dans le Centre du Bénin. Thèse de doctorat nouveau régime, Université d'Abomey,Calavi, Bénin.

Yabi, I., \& Afouda, F. (2012). Extreme Rainfall Years in Benin (West Africa). Quaternary International, 262, 39-43. https://doi.org/10.1016/j.quaint.2010.12.010 